\title{
H2AC12 wt Allele
}

National Cancer Institute

\section{Source}

National Cancer Institute. H2AC12 wt Allele. NCI Thesaurus. Code C162911.

Human H2AC12 wild-type allele is located in the vicinity of $6 \mathrm{p} 22.1$ and is approximately 1 $\mathrm{kb}$ in length. This allele, which encodes histone H2A type 1-H protein, plays a role in nucleosome remodeling. 